\title{
Seasonal Changes in the Mixing Rate of Restocked Ayu-juveniles and Assessment of Native Stock Using an Allozyme Marker
}

\author{
Shingo Seki, ${ }^{* 1}$ Nobuhiko Taniguchi, ${ }^{* 1}$ Naozumi Murakami, ${ }^{* 1}$ Akira Takamichi, ${ }^{* 1}$ \\ and Isao Takahashi*2 \\ ${ }^{* 1}$ Department of Cultural Fisheries, Faculty of Agriculture, Kochi University, Nankoku, Kochi 783, Japan \\ ${ }^{2}$ Nishinihon Institute of Technology, Kochi 780 , Japan
}

(Received August 6, 1993)

\begin{abstract}
Using an allozyme marker (i.e. $M P I^{*}$ ), we traced the mixing rate of the landlocked ayu-juveniles from Lake Biwa released in the Yasuda River and the Ioki River, inhabited by a native amphidromous form. We also estimated the population density based on under-water observations. The percentage of the landlocked form was remarkably high in the upper stream and very low in the lower stream in June. The percentage of the landlocked form decreased remarkably in the upper stream in both rivers in August. The percentage of the landlocked form decreased to almost zero in December. These seasonal changes in the mixing rate of the landlocked form suggested a difference in the migration pattern of the landlocked form and the amphidromous form in the river. The number of the amphidromous form coming up to the river from the sea was estimated using the landlocked form's percentage and the population density observed at each location during the early fishing season.
\end{abstract}

Key words: ayu, allozyme, marker, seasonal change

The ayu Plecoglossus altivelis is native to Southeastern Asia, e.g. the Japan Archipelago, part of the Korean Peninsula, and China. In Japan, the ayu is represented by both amphidromous and landlocked forms. The amphidromous form inhabits rivers flowing into the sea. The landlocked form is found mainly in Lakes Biwa and Ikeda. Juveniles of the landlocked form from Lake Biwa have been collected and restocked in rivers flowing into the sea for nearly seventy years. In recent years, about 500 tons (about 100 million individuals) of the landlocked form of ayu have been released annually into Japanese rivers inhabited by the amphidromous form.

Recently, it was reported that the landlocked form was genetically differentiated from the amphidromous form on the basis of biochemical genetic markers ${ }^{1-3)}$ and mtDNA. ${ }^{4)}$ Some researchers have reported that biological, physiological, and morphological characteristics were different between the landlocked and the amphidromous forms, e.g. territorial behavior, ${ }^{5,6}$ tolerance of water temperature, ${ }^{7)}$ spawning season, ${ }^{8)}$ fecundity and egg size, ${ }^{9)}$ and the number of longitudinal scales. ${ }^{10}$ Concerning the problem of reproduction of the released landlocked stock, some researchers have reported that the landlocked form did not hybridize with the amphidromous form, based on population genetic analysis. They also suggest that the landlocked form does not contribute to reproduction for the native population. ${ }^{1,2,4,11}$

In this report, we traced the released landlocked populations into rivers throughout the season using genetic markers. An attempt was also made to estimate the number of the amphidromous form based on the percentage of the landlocked population and the population density.

\section{Materials and Methods}

\section{Rivers Investigated}

The investigations were performed in the Yasuda and loki Rivers (Fig 1), the latter with a dam $26 \mathrm{~km}$ from its river mouth. This dam does not have fish ways. Therefore, the released ayu only inhabited the upper stream of the Ioki dam. The length of these rivers are $32 \mathrm{~km}$ and $43 \mathrm{~km}$. and their catchment areas are $111 \mathrm{~km}^{2}$ and $140 \mathrm{~km}^{2}$, respectively.

Samples

Samples were collected at five stations in the Yasuda River in 1988, and at five stations in the Ioki River in 1990 (Fig. 2-1, 2). Sampling was performed one to four times at each station in each river (Table 1) Collection was carried out by means of three fishing methods: "tomozuri" (angling by decoy), fishing by bait, and fishing by casting net. The amoun of juveniles of the landlocked form released in the rivers was about 239,000 fish in the Yasuda River from April to May, and 124,000 fish in the Ioki

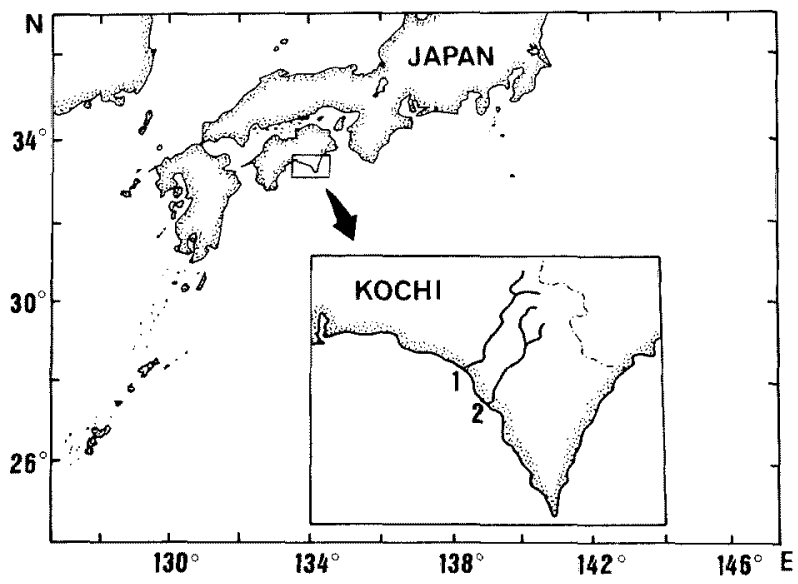

Fig. 1. Map of western Japan showing the areas of sampling collection. 1: Ioki River; 2: Yasuda River. 


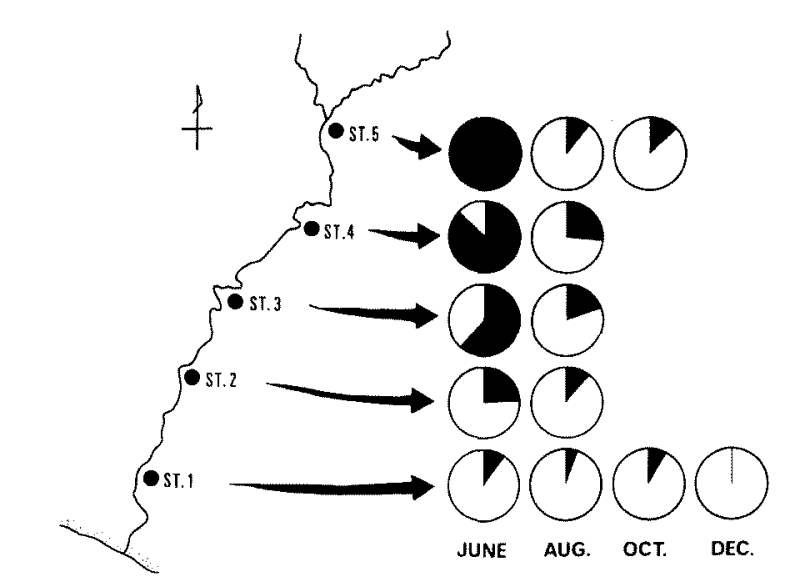

Pacific Ocean

Fig. 2-1. Percentage of the landlocked form in each station in the Yasuda River.

: The percentage of the landlocked form.

$\square$ : The percentage of the amphidromous form

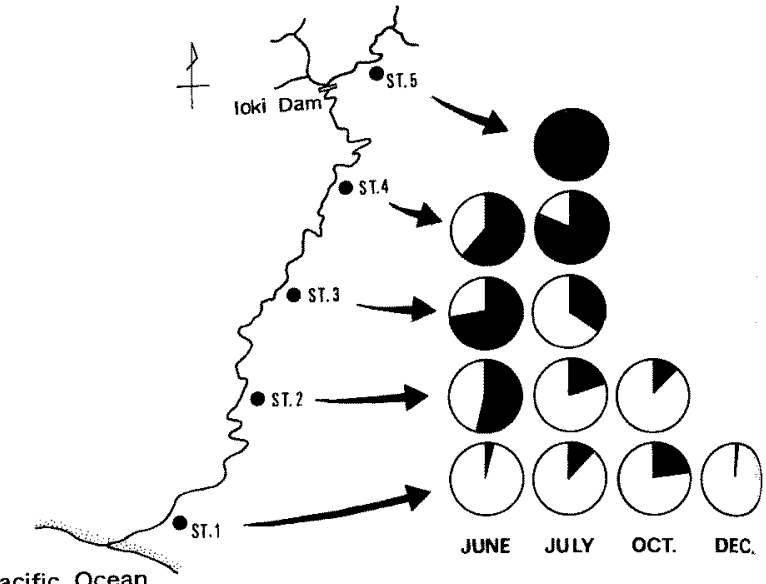

Pacific Ocean

Fig. 2-2. Percentage of the landlocked form in each station in the Ioki River.

E: The percentage of the landlocked form

$\square$ : The percentage of the amphidromous form.

Table 1. Body length of the sample taken in each station and each river, and the number of fish used in the parenthesis

\begin{tabular}{|c|c|c|c|c|c|c|}
\hline \multirow{2}{*}{ Sampling site } & \multirow{2}{*}{$\begin{array}{l}\text { Date of } \\
\text { collection }\end{array}$} & \multicolumn{5}{|c|}{ Range of fork length (mm) } \\
\hline & & St. 1 & St. 2 & St. 3 & St. 4 & St. 5 \\
\hline \multirow[t]{4}{*}{ Yasuda R. (1988) } & June 19 & $\frac{146.4 \pm 18.6^{* 1}}{(53)}$ & $\begin{array}{c}142.0 \pm 15.7^{* 1} \\
(51)\end{array}$ & $145.3 \pm \frac{ \pm}{(50)} 9.0^{* 1}$ & $157.9 \pm 9.9^{* \pm}$ & $143.7 \pm 11.1^{* 1}$ \\
\hline & Aug. 21 & $\frac{134.5 \pm 18.4^{* 1}}{(52)}$ & $142.0 \pm 17.7^{* 1}$ & $\begin{array}{c}163.6 \pm 17.2^{* 1} \\
(34)\end{array}$ & $\frac{158.7 \pm 16.5^{*}}{(52)}$ & $\begin{array}{c}167.9 \pm 16.9^{* 1} \\
(50)\end{array}$ \\
\hline & Oct. 2 & $\begin{array}{c}141.6 \pm 13.8^{* 1} \\
(50)\end{array}$ & - & - & - & $\frac{182.5 \pm 11.1^{* 1}}{(50)}$ \\
\hline & Dec. 1 & $\begin{array}{c}123.4 \pm 24.9^{* 2} \\
(60)\end{array}$ & - & - & - & - \\
\hline \multirow[t]{4}{*}{ Ioki R. (1990) } & June $1-8$ & $\begin{array}{c}90.9 \pm 18.6^{* 2} \\
(58)\end{array}$ & $\begin{array}{c}147.0 \pm 7.9^{* 2} \\
(71)\end{array}$ & $\begin{array}{c}128.5 \pm 13.5^{* 2} \\
(60)\end{array}$ & $\frac{145.8 \pm 12.4^{* 2}}{(53)}$ & - \\
\hline & July $19-31$ & $\begin{array}{c}103.7 \pm 21.9^{* 2} \\
(74)\end{array}$ & $\begin{array}{l}135.9 \pm 13.9^{* 2} \\
(110)\end{array}$ & $\begin{array}{c}144.1 \pm 17.2^{* 2} \\
(45)\end{array}$ & $\begin{array}{c}151.8 \pm 19.5^{* 2} \\
(20)\end{array}$ & $\begin{array}{c}158.7 \pm 12.9^{* 2} \\
(40)\end{array}$ \\
\hline & Oct. $9-12$ & $\begin{array}{l}125.9 \pm 27.2 * 2 \\
(109)\end{array}$ & $159.1 \pm 14.9 * 1$ & - & - & - \\
\hline & Dec. 1 & $\begin{array}{c}148.6 \pm 20.3^{* 2} \\
(58)\end{array}$ & - & - & - & - \\
\hline
\end{tabular}

*1: The angling by decoy

*2: The fishing by bait or the casting net

-: The fish was very few, and then it could collect hardly.

River from March to April. Furthermore, in early July, the released landlocked fish numbered 3,000 at Station 5 in the Yasuda River and 11,000 at Station 2 in the Ioki River.

\section{Electrophoresis and the Percentage Estimation}

We used horizontal starch gel electrophoresis for allozyme analysis. ${ }^{1,2)}$ Among the polymorphic and monomorphic allozymes detected, the $M P I^{*}$ locus was selected as the biochemical genetic marker which showed different allele frequency between the landlocked and amphidromous forms. ${ }^{2)}$ The standard value of $M P I^{*}$ allele frequencies for the two forms was mentioned in a previous paper. ${ }^{2)}$ Using the $M P I^{*} 100$ allele frequencies observed in the present study, the percentage of the landlocked form $\left(Y_{\mathrm{L}}\right)$ at each station was estimated on the basis of Sato's formula, ${ }^{121}$ as follows:

$$
Y_{\mathrm{L}}=\left\{\left(P_{\mathrm{O}}-P_{\mathrm{M}}\right) /\left(P_{\mathrm{L}}-P_{\mathrm{M}}\right)\right\} \times 100(\%)
$$

where $P_{0}$ represents the $M P I^{*}$ allele frequencies observed at each station, and $P_{\mathrm{L}}$ and $P_{\mathrm{M}}$ the standard value of $M P I^{*}$ allele frequencies for the landlocked and amphidromous form based on a previous paper, ${ }^{2)}$ respectively.
Population Density

The number of fish was counted by underwater direct observation. The counting was performed at each station two or three times. The observations were performed in $3 \mathrm{~m} \times 3 \mathrm{~m}$ squares at ten points in cach location. The population density at one station was represented by the average value of ten points in the Yasuda River. In the Ioki River, the line-census method was applied to calculate the population density. On the basis of these data, the number of the amphidromous form $(W)$ was estimated with Taniguchi's formula ${ }^{13}$ ) using the percentage of the landlocked form, the number of released landlocked fish, and the population density, as follows:

$$
W=R \times\left(N_{\mathrm{M}} / N_{\mathrm{L}}\right)
$$

and then,

$$
\begin{aligned}
& N_{\mathrm{L}}=\Sigma\left(D_{\mathrm{N}} \times S_{\mathrm{M}} \times Y_{\mathrm{L}} / 100\right) \\
& N_{\mathrm{M}}=\Sigma\left(D_{\mathrm{N}} \times S_{\mathrm{M}} \times Y_{\mathrm{M}} / 100\right)
\end{aligned}
$$

where $R$ was the number of released landlocked stock, $N_{\mathrm{M}}$ and $N_{\mathrm{L}}$ was 
the population density of the amphidromous and landlocked form, respectively, $D_{\mathrm{N}}$ was the population density of the total per $\mathrm{m}^{2}$ in each station, $S_{M}$ was the catching area in each station, and $Y_{M}$ was the percentage of amphidromous form in each station. $W$ was the number of the amphidromous form when the landlocked form was released in those rivers.

\section{Results}

Fluctuation of the Landlocked Form's Percentage and the Population Density

Table 2 indicates the $M P I^{*} 100$ allele frequencies in each station and the standard allele frequency of the amphidromous and the landlocked forms. Figures 2-1, 2 indicate seasonal changes in the percentage of the landlocked form in each river. Figure 3 indicates the population densities in each station.

In June in the Yasuda River, the percentage of the landlocked form in the upper stream was markedly higher than in the lower stream (Fig. 2-1); this value was extremely high at Station 5, where it reached $100 \%$. Meanwhile the population densities at Station 1 and Station 2 were much higher than those at Stations 3, 4, and 5 (Fig. 3). This suggested that the amphidromous form didn't yet go up to the upper stream in June. In August, the percentage of the landlocked form became lower than in June for all stations and decreased remarkably at Station 3,4, and 5, whereafter the population densities at Stations 2 to 5 decreased. After October, the percentage of the landlocked form became very low in both lower and upper streams. In October, the

\section{Yasuda River}

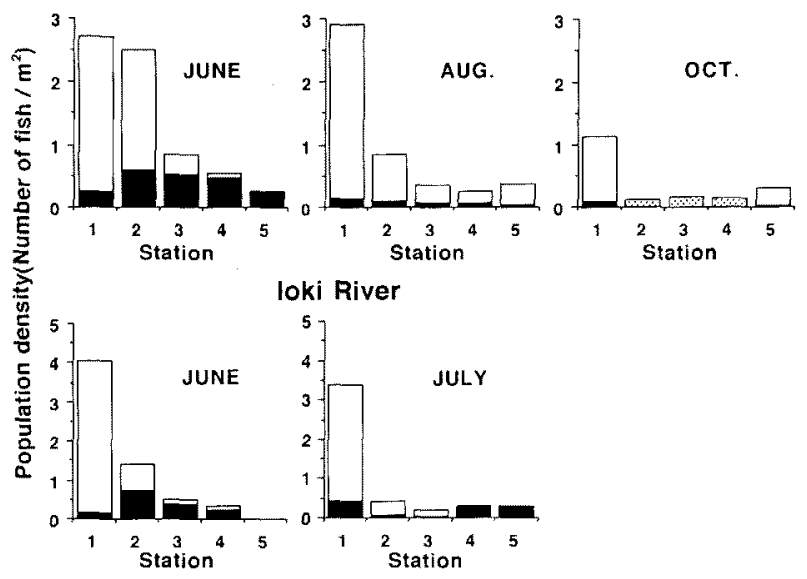

Fig. 3. Population density in each river.

口: The rate of landlocked population.

D: Population density where it was not possible to estimate the rate of landlocked population.

Table 2. $M P I^{*} 100$ allele frequencies in each station and each river

\begin{tabular}{|c|c|c|c|c|c|c|}
\hline \multirow{2}{*}{ Sampling site } & \multirow{2}{*}{$\begin{array}{l}\text { Date of } \\
\text { collection }\end{array}$} & \multicolumn{5}{|c|}{$M P I^{*} 100$ allele frequency $\pm \mathrm{CL}_{0.95}$} \\
\hline & & St. 1 & St. 2 & St. 3 & St. 4 & St. 5 \\
\hline \multirow[t]{4}{*}{ Yasuda R. (1988) } & June & $0.830 \pm 0.072$ & $0.755 \pm 0.086$ & $0.560 \pm 0.100$ & $0.420 \pm 0.098$ & $0.333 \pm 0.094$ \\
\hline & Aug. & $0.856 \pm 0.068$ & $0.820 \pm 0.076$ & $0.779 \pm 0.102$ & $0.740 \pm 0.086$ & $0.820 \pm 0.076$ \\
\hline & Oct. & $0.840 \pm 0.074$ & - & $\ldots$ & - & $0.820 \pm 0.038$ \\
\hline & Dec. & $0.892 \pm 0.028$ & - & - & - & - \\
\hline \multirow[t]{4}{*}{ Ioki R. (1990) } & June & $0.862 \pm 0.064$ & $0.606 \pm 0.082$ & $0.500 \pm 0.092$ & $0.557 \pm 0.096$ & - \\
\hline & July & $0.818 \pm 0.064$ & $0.777 \pm 0056$ & $0.700 \pm 0.096$ & $0.450 \pm 0.165$ & $0.338 \pm 0.107$ \\
\hline & Oct. & $0.761 \pm 0.058$ & $0.815 \pm 0.074$ & - & - & - \\
\hline & Dec. & $0.879 \pm 0.060$ & - & $-\ldots$ & 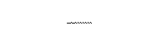 & $-\ldots$ \\
\hline Amphidromous & & $0.881^{*}$ & & & & \\
\hline Landlocked & & $0.355^{*}$ & & & & \\
\hline
\end{tabular}

*: The basic value from the previous report. ${ }^{11}$

Table 3. Population density per $\mathrm{m}^{2}$ and the spaces in each station and each river in June

\begin{tabular}{|c|c|c|c|c|c|c|c|}
\hline \multirow{2}{*}{ Sampling site } & \multirow{2}{*}{$\begin{array}{l}\text { Sampling } \\
\text { station }\end{array}$} & \multirow{2}{*}{$\begin{array}{l}\text { Population } \\
\text { density } \\
\text { per } \mathrm{m}^{2}\end{array}$} & \multirow{2}{*}{$\begin{array}{c}\text { Percentage of } \\
\text { landlocked form } \\
(\%)\end{array}$} & \multirow{2}{*}{$\begin{array}{c}\text { Space in } \\
\text { each station } \\
\left(\mathrm{m}^{2}\right)\end{array}$} & \multicolumn{2}{|c|}{ Estimated number } & \multirow{2}{*}{$\begin{array}{c}\text { Number of } \\
\text { landlocked form } \\
\text { released }\end{array}$} \\
\hline & & & & & Amphi. & Land. & \\
\hline \multirow[t]{6}{*}{ Yasuda R. } & St. 1 & 2.72 & 9.7 & 80,250 & 197,107 & 21,173 & 5,000 \\
\hline & St. 2 & 2.50 & 24.0 & 187,420 & 356,098 & 112,452 & 52,000 \\
\hline & St. 3 & 0.85 & 61.0 & 47,000 & 15,581 & 24,370 & 52,000 \\
\hline & St. 4 & 0.54 & 87.6 & 29,600 & 1,982 & 14,002 & 44,000 \\
\hline & St. 5 & 0.27 & 100.0 & 29,600 & 0 & 7,992 & 86,000 \\
\hline & Total & 2.01 & & 373,870 & 570,768 & 179,989 & 239,000 \\
\hline \multirow{5}{*}{ Ioki $\mathbf{R}$. } & St. 1 & 4.04 & 3.6 & 75,910 & 295,636 & 11,040 & 41,000 \\
\hline & St. 2 & 1.40 & 52.3 & 79,470 & 53,070 & 58,188 & 31,000 \\
\hline & St. 3 & 0.51 & 72.4 & 64,000 & 9,009 & 23,631 & 19,000 \\
\hline & St. 4 & 0.35 & 61.6 & 118,400 & 15,913 & 25,527 & 33,000 \\
\hline & Total & 1.46 & & 337,780 & 373,628 & 118,386 & 124,000 \\
\hline
\end{tabular}


population density was very low at most stations except Station 1. The population densities were very low at Stations 2,3 , and 4 , thus it was rather difficult to collect the fish at those stations, because the fish had moved to the lower stream. The pattern of fluctuation in the Ioki River was similar to that in the Yasuda River, although the values in the Ioki River were slightly higher than those in the Yasuda River, especially in the upper stream after July (Fig. 2-2). Since the amphidromous form is unable to go up to Station 5 owing to the barrier of the Ioki dam, the percentage of the landlocked form at this station was $100 \%$ even in July (Fig. 2-2).

\section{Estimation of the Number of the Amphidromous Form}

The number of the amphidromous form was estimated on the basis of the percentage of the landlocked form and the population densities in June, as well as the catchment area in the river (Table 3 ). As the estimated number of the landlocked fish was different from that of the released ones at each location, we concluded that the released landlocked fish dispersed throughout the river and mixed uniformly. The estimated total number of landlocked fish and amphidromous fish were 179,989 and 570,768 in the Yasuda River, and 118,386 and 373,628 in the Ioki River, respectively. The total number of the amphidromous form was 757,899 fish in the Yasuda River and 391,346 in the loki River.

\section{Discussion}

Restocking of the landlocked form of ayu into natural rivers has been carried out in order to enhance existing natural resources, but it used to be uncertain whether the released stock of the landlocked form contributed to the reproduction of the native population. Looking at the present data in the Yasuda River, the percentage of the landlocked form was higher in June than in other seasons and also higher in the upper than in the lower parts. This result is related to the upstream migration of the amphidromous form. In June, the native population (amphidromous form) has not come up the river as far as the upper stream. In fact, the percentage of the amphidromous form was found to be very high only in the lower stream. The fishing season for ayu is June to November, and thus the released fish (landlocked form) cannot be caught until the first of June. In addition, these fish grow faster than the native ones, because of the high availability of food in that early part of the year. Consequently, the exploitation rate of the landlocked form will be higher than that of the amphidromous form, because of the selective fishing of the larger ones ${ }^{14)}$ which have stronger territorial activity. ${ }^{5,6)}$ The population density also decreased remarkably in the upper and middle streams, although it remained almost constant in the lower stream. By October, the population densities decreased remarkably in the middle stream, while the percentage of landlocked form saw a little increase in the lower stream. There is little difference in the pattern of seasonal change in the percentage between the rivers. The percentage of the landlocked form was lower in the Ioki River than in the Yasuda River, because the released fish were fewer in the Ioki River than in the Yasuda River and the sampling method was by cast- ing net in the Ioki River. In July, the percentage of the landlocked form in the lower stream (Stations 1 and 2) was higher than in the corresponding points in the Yasuda River. It is possible that these percentages increased thanks to the landlocked fish released in early July.

The pattern of seasonal change in each river suggests that the landlocked fish decreased markedly in the upper and middle stream by October, and that the landlocked fish went down to the lower stream for spawning in October. If some of the few surviving individuals of the landlocked form were to spawn in late September, the larvae would have difficulty in surviving in the sea, since the water temperature is still higher than that which is appropriate for the ayu larvae. It is known that the temperature tolerance limit of the landlocked form is lower than that of the amphidromous form. ${ }^{7)}$ In a survey of ayu larvae during sea life made with genetic markers, landlocked form larvae were hardly found. ${ }^{15)}$ The present report and this fact suggest that the reproduction of the landlocked form does not succeed in the area where the fish were released.

There are many instances of genetic differentiation between two ecological types within a species. Some studies on these have reported gene introgression between the two types. ${ }^{16-18)}$ For example, in rainbow trout, genetic introgression was observed between native and nonnative populations which had the same spawning season and behavior. ${ }^{17)}$ On the other hand, gene introgression did not occur between the two forms of Atlantic salmon, because the two types have different spawning behavior. ${ }^{19)}$ The case of the ayu is similar to the latter in view of the difficulty of the gene introgression.

It was suggested that the landlocked form hardly reproduced in the river where it had been restocked. This is desirable for the conservation of genetic divergence in natural populations of the ayu. The landlocked form can be regarded as a tag fish, useful to estimate the amount of native population density. The assessment of ayu native resources is important for stock management in fresh water fisheries. It has been difficult to estimate the amount of the amphidromous form coming into the rivers; some estimation methods were based on the number of hatched larvae flowing down to the sea, or by directly counting the number of fish coming up to the river mouth, although these methods require a great effort. On the other hand, the present study, which used the genetic marker of the restocked landlocked form, was considered to be more convenient than the other methods in assessing ayu native resources during upstream migration. It was also suggested that this method was reliable for estimating the number of amphidromous fish based on the coincidence of the actual number of released fish with its estimated number using an isozyme marker. We think that the resources assessment will become more exact than those in the present study by increasing samples and locations.

Acknowledgement We thank Ms. S. S. Siraj and Ms. Gabriela Del Valle $\mathrm{P}$. for their critical reading of the manuscript.

\section{References}

1) N. Taniguchi, S. Seki, and Y. Inada: Genetic variability and differentiation of amphidromous, landlocked, and hatchery popula. tions of ayu Plecoglossus altivelis. Nippon Suisan Gakkaishi, 49, 
1655-1663 (1983)

2) S. Seki, N. Taniguchi, and S. Jeon: Genetic divergence among natura populations of ayu from Japan and Korea. Nippon Suisan Gakkaishi 54, 559-568 (1988).

3) M. Nishida: Substantial genetic differentiation in ayu Plecoglossus altivelis of the Japan and Ryukyu Islands. Nippon Suisan Gakkaishi, 51, 1269-1274 (1985)

4) L. A. Pastene, K. Numachi, and K. Tsukamoto: Examination of reproductive success of transplanted stock in an amphidromous fish, Plecoglossus altivelis (Temmink et Schlegel) using mitochondrial DNA and isozyme markers. J. Fish. Biol., 39(Suppl. A), 93-100 (1991).

5) Y. Wada: Territorial behavior in three types of ayu (landlocked, amphidromous and hatchery types). Ayu, Amago Jinkou Shubyo Houkokusyo, 9, 71-75 (1977) (in Japanese)

6) S. Seki, N. Taniguchi, K. Murakami, and M. Yoneda: Comparative experiments on growth, maturation, and ethological property of landlocked and amphidromous forms of ayu, Plecoglossus altivelis. The Freshwater Fishes, 10, 101-104 (1984).

7) K. Tabata and M. Azuma: Survival of three types of ayu fish Plecoglossus altivelis fry in sea water rearing. Bull. Hyogo Pref. Fish. Exp. Stn., 24, 29-34 (1986).

8) Y. Honma and E. Tamura: Seasonal changes in the gonads of landlocked salmonid fish, Ko-ayu, Plecoglossus altivelis TEMMINCK et Schlegel. Japan. J. Ichthyol., 9, 135-152 (1962).

9) M. Azuma: Study on the variability of the landlocked ayu-fish, Plecoglossus altivelis $\mathbf{T}$. et $\mathrm{S}$., in Lake Biwa. III. On the differences in the process of maturation, spawning habits, and some morphological features of each population. Japan. J. Ecol., 23, 147-159 (1973).

10) M. Nishida and Y. Sawashi: Geographic differences in the number of longitudinal scales of the ayu Plecoglossus altivelis. Nippon Suisan Gakkaishi, 53, 2089 (1987).

11) S. Seki and N. Taniguchi: Tracking the released ayu of landlocked form by isozyme markers. Nippon Suisan Gakkaishi, 54, 745-749 (1988).

12) R. Sato, K. Naka, and R. Ishida: Application of isozyme as a genetic marker for fish farming. Fish Genet. Breeding $S c i$, 7, 1-8 (1982).

13) N. Taniguchi and I. Takahashi: Tracking ayu seed restocked in the population of Nakagawa river using biochemical genetic markers. Monthly Kaiyo, 21, 270-276 (1989) (in Japanese).

14) R. Ishida: On the size of ayu, Plecoglossus altivelis T. \& S., caught by 'Tomozuri'. Bull. Freshwater Fish. Res. Lab., 14, 29-36 (1964).

15) K. Azuma, I. Kinoshita, S. Fujita, and I. Takahashi: GPI isozyme and birth dates of larval ayu, Plecoglossus altivelis in the surf zone. Japan. J. Ichthol., 35, 493-496 (1989).

16) C. A. Busack and G. A. E. Gall: Introgressive hybridization in populations of Paiute cutthroat trout (Salmo clarki seleniris). Can. J. Fish. Aquat. Sci., 38, 939-951 (1981).

17) D. E. Campton and J. M. Johnston: Electrophoretic evidence for a genetic admixture of native and nonnative rainbow trout in the Yakima River, Washington. Trans. Amer. Fish. Soc., 114, 782-793 (1985).

18) T. E. Dowling, G. R. Smith, and W. M. Brown: Reproductive isolation and introgression between Notropis cornutus and Notropis chrysocephalus (Family Cyprinidae): Comparison of morphology allozymes, and mitochondrial DNA. Evolutions, 43, 620-634 (1989).

19) T. P. Birt, J. M. Green, and W. S. Davidson: Mitochondrial DNA variation reveals genetically distinct sympatric populations of anadromous and nonanadromous Atlantic salmon, Salmo salar. Can J. Fish. Sci., 48, 577-582 (1991). 